\title{
PENERAPAN MODEL KANO-IGA DALAM ANALISIS KEPUASAN KERJA KARIR AWAL KARYAWAN
}

\author{
Ronald Sukwadi, Yolenta Michelle P.P. \\ Program Studi Teknik Industri \\ Universitas Katolik Indonesia Atma Jaya \\ Jalan Jenderal Sudirman 51 Jakarta 12930 \\ ronald.sukwadi@atmajaya.ac.id; micheleputri@gmail.com
}

\begin{abstract}
Abstrak
Karir awal merupakan tahapan pertama di mana seseorang memasuki sebuah perusahaan. Tahap ini merupakan tahap penekanan pada perhatian untuk memperoleh jaminan terpenuhinya kebutuhan dalam tahun-tahun awal pekerjaannya. Penelitian ini bertujuan untuk mengetahui faktor-faktor apa saja yang harus diperhatikan dalam pemenuhan kepuasan kerja karyawan yang bekerja kurang dari 1 tahun (karir awal). Integrasi model Kano dan Importance Grid Analysis (IGA) digunakan dalam mengidentifikasi dan memprioritaskan faktor-faktor tersebut. Dari penelitian diperoleh hasil bahwa faktor-faktor yang harus diperhatikan perusahaan dalam awal karir seseorang adalah: rekan kerja, fasilitas kerja, atasan, kerjasama tim, gaji, pekerjaannya, lingkungan kerja, pelatihan kerja, penjadwalan kerja, sistem kerja, jam kerja, dan beban kerja.
\end{abstract}

Kata kunci: Kepuasan kerja, model Kano, Importance Grid Analysis

\section{PENDAHULUAN}

Kepuasan kerja seorang karyawan merupakan salah satu yang menjadi faktor keberlangsungan bisnis pada suatu perusahaan tertentu. Perusahaan tersebut harus terus melakukan perbaikan demi memenuhi kepuasan kerja para karyawannya sehingga karyawan dalam perusahaan tersebut mengalami kenyamanan dalam bekerja. Seseorang yang sudah memiliki rasa nyaman dan aman dalam melakukan suatu pekerjaan akan berusaha keras dalam menjalankan pekerjaannya. Sehingga jika karyawan tersebut selalu bekerja keras dalam pekerjaannya akibatnya karyawan tersebut akan menghasilkan suatu hal yang baik dalam pekerjaannya.

Kepuasan kerja merupakan suatu hal yang bersifat pribadi atau individual. Setiap orang memiliki tingkat kepuasan yang berbeda. Kepuasan itu terjadi apabila kebutuhan-kebutuhan individu itu sendiri sudah terpenuhi dan terkait dengan derajat kesukaan dan ketidaksukaan karyawan (Robbins dan Judge, 2017). Untuk memenuhi kepuasan kerja seorang karyawan memiliki faktor-faktor yang akan mempengaruhi kepuasan kerja tersebut diantaranya adalah: imbalan yang pantas, kondisi kerja yang mendukung, rekan kerja yang mendukung, kesesuaian karyawan dengan pekerjaannya.

Untuk mempertahankan sebuah perusahaan dibutuhkan karyawan-karyawan yang produktif. Karyawan disebuah perusahaan akan terus berganti yang disebabkan beberapa faktor seperti usia pekerja yang sudah memasuki usia lanjut, atau pekerja yang tidak produktif dan yang lainnya. Perusahaan harus tetap mendapatkan dan mempertahankan pekerja yang produktif. Dalam hal ini, perusahaan harus menarik karyawan baru yang berkompeten.

Fokus dalam penelitian ini adalah awal karir seroang karyawan, yaitu dengan lama kerja kurang dari 1 tahun. Biasanya seorang karyawan yang bekerja kurang dari 1 tahun masih mencari pekerjaan yang kira-kira tepat untuk mereka. Kepuasan kerja menjadi salah satu faktor yang mempengaruhi keinginan berpindah pada karyawan (Sukwadi \& Meliana, 2015). Untuk melakukan penelitian kepuasan kerja terdapat beberapa metode seperti Job Descriptive Index (JDI) atau Minnesota Satisfaction Questionnaire (MSQ) tetapi pada penelitian ini digunakan model Kano. Hal ini dikarenakan pada metode JDI dan MSQ tidak memperhitungkan variabel perbedaan individu untuk melakukan suatu pekerjaan. Seperti kebutuhan karyawan atas gaji, promosi dan yang lainnya. Sedangkan pada metode Kano setiap perbedaan aspek kebutuhan kerja akan memberikan efek kepuasan kerja yang berbeda. 
Atribut kepuasan yang digunakan berdasarkan pertanyaan terbuka dengan kuesioner pendahuluan yang kemudian akan disusun menggunakan diagram anifitas. Setelah mendapatkan atribut tersebut akan dilakukan analisis atribut menggunakan metode Improtance Grid Analysis (IGA). Metode ini untuk mengklasifikasikan atribut pada model kano yang akan digunakan pada penelitian ini. Tujuan dari penelitian ini adalah untuk mengidentifikasi dan memprioritaskan faktor-faktor yang harus diperhatikan dalam pemenuhan kepuasan kerja karyawan pada awal karirnya.

\section{LANDASAN TEORI}

\section{A. Kepuasan Kerja}

Menurut Hasibuan (2007) Kepuasan kerja adalah sikap emosional yang menyenangkan dan mencintai pekerjaannya. Kepuasan kerja (job statisfaction) harus dijaga seabaik mungkin agar dapat meningkatkan moral kerja, dedikasi, kecintaan, dan kedisiplinan karyawan. Kepuasan kerja dinikmati dalam pekerjaan, luar pekerjaan, dan kombinasi dalam dan luar pekerjaan. Kepuasan kerja dalam pekerjaan adalah kepuasan kerja yang dinikmati dalam pekerjaan dengan memperoleh pujian hasil kerja, penempatan, perlakuan, peralatan, dan suasana lingkungan kerja yang baik. Karyawan yang lebih suka menikmati kepuasan kerja dalam pekerjaan akan lebih mengutamakan pekerjaannya daripada balas jasa walaupun balas jasa itu penting.

Robbins dan Judge (2017) mendefinisikan kepuasan kerja sebagai perasaan positif tentang pekerjaan sebagai hasil evaluasi karakter-karakter pekerjaan tersebut. Selain itu, Noe dkk (2006) mendefinisikan kepuasan kerja sebagai perasaan yang menyenangkan sebagai hasil dari persepsi bahwa pekerjaannya memenuhi nilai-nilai pekerjaan yang penting. Kemudian pernyataan tersebut dikuatkan oleh pernyataan Kinicki dan Kreitner (2005) yang mendefinisikan kepuasan kerja merupakan respon sikap atau emosi terhadap berbagai segi pekerjaan seseorang. Definisi yang diberikan tersebut mengatakan bahwa kepuasan kerja bukan suatu konsep tunggal. Lebih dari itu seseorang dapat secara relatif dipuaskan dengan satu aspek pekerjaannya dan dibuat tidak puas dengan satu atau berbagai aspek. Nelson dan Quick (2006) mengatakan kepuasan kerja merupakan suatu kondisi emosional yang positif dan menyenangkan sebagai hasil dari penilaian pekerjan atau pengalaman pekerjaan seseorang.

\section{B. Model Kano}

Metode Kano dikembangkan oleh Dr. Noriaki Kano (Kano dkk,1984). Model ini bertujuan untuk mengkategorikan atribut-atribut layanan berdasarkan seberapa baik layanan tersebut mampu memuaskan kebutuhan pelanggan seperti pada penelitian Sukwadi dan Yang (2014), Sukwadi dkk (2015), Fan dkk (2015), dan Sukwadi dan Agustin (2016). Secara umum, atributatribut layanan tersebut dapat dibedakan menjadi enam kategori yaitu: (1) Attractive (excitement needs), (2) One dimensional (performance needs), (3) Must be (basic needs), (4) Indefferent, (5) Reverse, dan (6) Questionable (Witell dan Lofgren, 2007).

Attractive (excitement needs) merupakan kategori yang tingkat kepuasan pelanggan akan meningkat sangat tinggi dengan meningkatnya kinerja atribut. Penurunan kinerja atribut tidak akan menyebabkan penurunan tingkat kepuasan. One dimensional (performance needs) adalah kategori yang apabila terpenuhi maka dapat meningkatkan kepuasan pelanggan dan akan menyebabkan ketidakpuasan bila tidak terpenuhi. Tingkat kepuasan pelanggan berhubungan linier dengan kinerja atribut, sehingga menurunnya kinerja atribut akan menurunkan pula tingkat kepuasan pelanggan.

Kategori Must be (basic needs) merupakan kategori dimana pelanggan menjadi tidak puas apabila kinerja dari atribut yang bersangkutan rendah tetapi kepuasan pelanggan tidak akan meningkat jauh diatas netral meskipun kinerja dari atribut tersebut tinggi. Kategori ini merupakan kebutuhan dasar yang harus dipenuhi oleh penyedia jasa kepada pelanggannya. Kategori Indefferent terjadi jika ada maupun tidaknya layanan tidak akan memberikan pengaruh kepada kepuasan konsumen. Kategori Reverse merupakan kategori kebalikan dari kategori One dimensional, di mana derajat kepuasan pelanggan lebih tinggi jika layanan diberikan tidak 
semestinya, dibandingkan layanan yang berjalan lebih baik. Terakhir adalah kategori Questionable merupakan kondisi yang kadangkala pelanggan puas atau tidak puas jika layanan itu diberikan atau tidak diberikan.

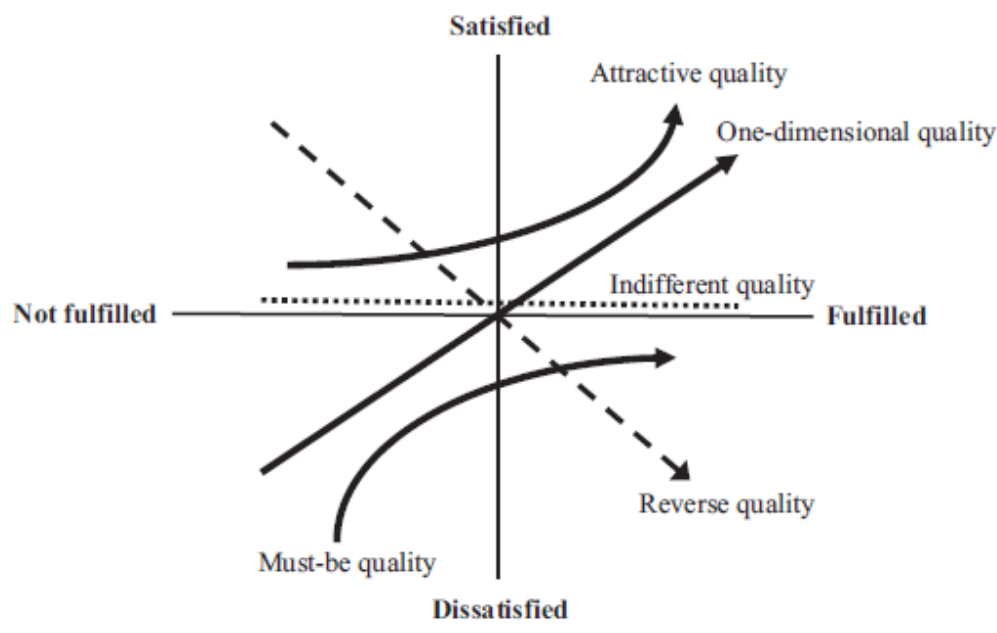

Gambar 1. Model Kano (Kano dkk, 1984)

\section{Importance Grid Analysis (IGA)}

Importance Grid Analysis (IGA) merupakan sebuah alat penelitian yang dikembangkan untuk membuat kategorisasi atribut sesuai dengan model Kano. Jika kita menggunakan IGA untuk mengkategorikan suatu atribut yang akan diteliti harus dibuat beberapa asumsi implisit (Mikulić dan Prebežac, 2011). Dengan demikian untuk memvalidasi asumsi yang dibuat perlu adanya penilaian apakah asumsi yang dibuat logis.

Asumsi 1: Langkah-langkah eksplisit dan implisit dari AI menilai konsep yang berbeda. Karena IG menggunakan dua langkah AI yang berbeda untuk menentukan kategori atribut ini sesuai dengan Model Kano, asumsi yang paling mendasar bahwa langkah-langkah yang ada pada AI menilai konsep yang berbeda.

Asumsi 2: Explicit AI merupakan indikator ketidakpuasan yang menghasilkan atribut ini potensial (DGP). Ketika eksplisit AI tinggi, atribut yang baik dikategorikan sebagai BF atau PF dengan tingkat kepentingan yang tinggi $(\mathrm{PF}+)$. Asumsi eksplisit AI menjadi indikator DSG karenanya harus dipertimbangkan dengan hati-hati.

Asumsi 3: Implisit AI merupakan indikator kepuasan yang menghasilkan atribut potensial (SGP). Ketika implisit AI tinggi, atribut yang baik dikategorikan sebagai EF atau PF +. Ini adalah dua kategori atribut dengan dampak positif yang kuat pada OS ketika kinerja tinggi. Masukan sebaliknya, prasyarat yang diperlukan untuk atribut memiliki dampak positif yang kuat pada OS ketika melakukan tinggi adalah bahwa ia memiliki implisit AI yang tinggi.

Asumsi 4: Positioning atribut relatif mengungkapkan kategori atribut yang berbeda menurut model Kano. Karena IG menerapkan pendekatan data yang berpusat untuk menentukan nilai ambang kategori Kano yang berbeda (yaitu garis bidik yang membagi IG menjadi empat kuadran), untuk atribut semua atribut lainnya yang dimasukkan dalam analisis mewakili titik referensi dalam menentukan kategori sendiri.

\section{METODOLOGI PENELITIAN}

\section{A. Alur Penelitian}

Secara umum, penelitian yang dilakukan mengikuti alur metodologi penelitian sebagai berikut: 


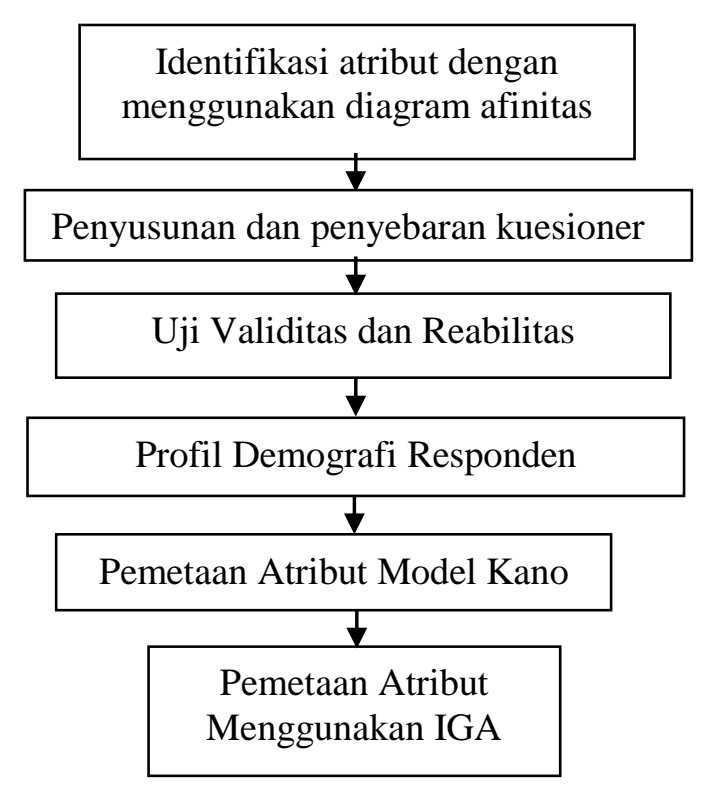

Gambar 2. Metodologi penelitian

\section{Identifikasi Atribut Kuesioner dengan Menggunakan Diagram Afinitas}

Tahap ini merupakan tahap untuk mengidentifikasi atribut yang diinginkan oleh karyawan. Pada tahap sebelumnya didapatkan hasil kuesioner pendahulu yang berupa atribut-atribut kepuasan kerja. Atribut-atribut tersebut akan dikelompokan berdasarkan arti kata yang sama. Pengelompokan ini dengan menggunakan diagram afinitas. Setelah didapatkan daftar kelompok atribut tersebut maka akan dilakukan penyortiran. Penyortiran tersebut dilakukan agar daftar atribut tersebut lebih ringkas. Untuk meringkas daftar atribut menggunakan metode analisis chi-square dan pareto. Hasil yang di dapatkan dari analisis statistik ini merupakan atribut-atribut yang menonjol atau diinginkan oleh karyawan.

\section{Penyusunan dan Penyebaran Kuesioner}

Tahap ini merupakan tahap untuk merancang kuesioner yang akan disebarkan kepada objek penelitian yaitu karyawan yang bekerja kurang dari 1 tahun. Atribut digunakan pada penelitian ini telah ditentukan pada tahap sebelumnya. Kuesioner ini disusun berdasarkan metode Kano. Pada metode ini kuesioner dibagi menjadi empat bagian yaitu:

a) Bagian pertama merupakan identitas responden seperti inisial nama dan tanda tangan.

b) Bagian kedua kuesioner yaitu karakteristik responden seperti umur, lama bekerja, pendidikan terakhir, jenis kelamin.

c) Bagian ketiga merupakan functional questions. Functional questions merupakan pertanyaan yang menyatakan kondisi yang diharapkan oleh responden jika atributatribut tersebut terpenuhi.

d) Bagian keempat terdiri atas dysfunctional question. Dysfunctional question menyatakan kondisi yang dirasakan responden jika atribut-atribut tertentu yang telah ditentukan tidak terpenuhi.

\section{Uji Validitas dan Reliabilitas}

Pada tahap ini hasil kuesioner yang didapatkan akan diuji apakah valid atau tidaknya dengan menggunakan bantuan software SPSS 21. Setelah mengetahui validitas dari atributatribut tersebut, kemudian dilakukan uji reabilitasnya. 


\section{Profil Demografi Responden}

Pada tahap ini masing-masing demografi responden akan dihitung persentasenya agar peneliti mengetahui berapa besar persentase objek-objek yang diteliti seperti berdasarkan jenis kelamin, umur, dan lainnya.

\section{Pemetaan Atribut Model Kano}

Pada tahap ini, semua hasil yang didapatkan dari tahap sebelumnya akan dimasukan ke dalam tabel evaluasi Kano. Pada tahap ini aka memperoleh jumlah responden untuk kategori One-dimensional (O), Must be (M), Questionable (Q), Attractive (A), Reverse (R), dan Indefferent (I). Setelah mendapatkan hasil perhitungan evaluasi tabel Kano yang dihitung berdasakan hasil kuesioner responden akan dipetakan sesuai masing-masing kategori kepuasan kerja pada masing-masing atribut digunakan Blauth's formula.

\section{Pemetaan Atribut Menggunakan IGA}

Tahap ini merupakan tahap untuk memetakan atribut-atribut yang sudah dihitung pada tahap sebelumnya. Pemetaan menggunakan metode IGA akan melengkapi model Kano ini menggunakan diagram kartesius yaitu diagram yang terbagi atas empat kuadran. Langkah pertama yang dilakukan dengan menentukan kepentingan implisit dan eksplisit. Kemudian hitung rata-rata dari kedua faktor tersebut. Dari rata-rata yang telah didapatkan akan dibuat 4 kuadran. Selanjutnya masukan kategori atribut dari model Kano ke dalam 4 kuadran tersebut. Pada kuadran satu berisikan atribut-atribut yang harus diprioritaskan terlebih dahulu. Untuk kuadran dua merupakan kuadran atribut yang harus dipertahankan. Pada kuadran tiga merupakan atribut yang prioritasnya rendah, sedangkan pada kuadran terakhir atau kuadran empat merupakan atribut yang berlebihan.

\section{B. Desain Riset}

Pada penelitian ini digunakan metode nonprobability sampling dengan metode judgemental random sampling. Responden pada penelitian ini adalah karyawan yang bekerja kurang dari 1 tahun yang berada di Jakarta. Sampel untuk kuesioner pendahuluan sebanyak 50 karyawan, kemudian untuk kuesioner penelitian akan diambil sebanyak 200 karyawan. Periode pengambilan sampel pada bulan Oktober- Desember 2016.

\section{HASIL DAN PEMBAHASAN}

Setelah mendapatkan hasil dari kuesioner pendahuluan, jawaban-jawaban atas pertanyaan terbuka pada kuesioner tersebut akan dirangkum menggunakan diagram afinitas. Untuk mendapatkan diagram afinitas hal yang perlu dilakukan yaitu mengelompokkan hasil kuesioner pendahuluan dengan kesamaan arti atau sinonim. Setelah itu kelompok-kelompok tersebut akan diberikan nama.

Berdasarkan hasil yang di dapat untuk pertanyaan kesenangan atau kesukaan. Dari 53 ide mengenai faktor kesenangan dalam bekerja, didapatkan 12 kelompok kategori atribut yaitu pengalaman, lingkungan kerja, rekan kerja, pekerjaannya, gaji, atasan penghargaan kerja, tantangan, fasilitas, kesesuaian pekerjaan, sistem kerja, others. Dari ke 12 kelompok kategori tersebut, 11 ide berada pada kelompok kategori atribut rekan kerja kemudian 9 untuk kategori lingkungan kerja. 7 untuk kelompok kategori Gaji dan pekerjaannya.

Untuk pertanyaan kedua yaitu mengenai ketidaksenangan atau ketidaksukaan para responden terdapat 12 kelompok kategori atribut yaitu lingkungan kerja, atasan, jam kerja, penjadwalan kerja, kerjasama tim, rekan kerja, beban kerja, gaji, fasilitas, kesesuaian pekerjaan, sistem kerja, dan others. Dari 12 kelompok kategori tersebut, karyawan perusahaan jasa yang bekerja kurang dari 1 tahun memilih kelompok kategori atasan yang mereka tidak suka dengan 10 responden, 8 responden tidak menyukai rekan kerja mereka, kemudian untuk kelompok kategori beban kerja, kerja sama tim dan jam kerja. 
Sedangkan kelompok kategori untuk pertanyaan faktor yang dapat ditingkatkan oleh perusahaan dalam pekerjaan terdapat 9 kelompok kategori yang terbentuk yaitu gaji, pelatihan, sistem kerja, penjadwalan kerja, fasilitas, kerjasama tim, beban kerja, lingkungan kerja, dan atasan. Dari ke 9 kategori tersebut kategori yang paling banyak dipilih oleh responden dengan 10 poin yaitu mengenai pelatihan kerja, kemudian penjadwalan kerja dengan 9 poin.

Yang terakhir yaitu pertanyaan mengenai faktor yang membuat para karyawan kembali setiap harinya. Berdasarkan hasil kuesioner yang dirangkum kedalam diagram afinitas terdapat 10 kelompok kategori atribut yaitu pengalaman, lingkungan kerja, gaji, rekan kerja, pekerjaannya, fasilitas, kerjasama tim, tantangan, jarak, dan others. Dari ke sepuluh kelompok tersebut, kelompok kategori yang paling banyak dipilih yaitu lingkungan kerja dengan 15 poin, gaji dengan 12 poin, rekan kerja 9 poin. Kemudian dari semua atribut tersebut di rangkum menggunakan Chi-Square. Berdasarkan perhitungan Chi-Square terdapat 12 atribut-atribut yang akan digunakan pada kuesioner utama. Atribut tersebut yaitu : Lingkungan kerja, rekan kerja, pekerjaannya, gaji, atasan, jam kerja, kerjasama tim, beban kerja, pelatihan kerja, sistem kerja, penjadwalan kerja dan fasilitas. Berikut hasil perhitungan Chi-square:

Tabel 1. Tabel Perhitungan Chi-Square (Likes)

\begin{tabular}{lccccc}
\hline \multicolumn{1}{c}{ Variabel } & Observed & Expected & O-E & $(\mathrm{O}-\mathrm{E})^{\wedge} 2$ & $(\mathrm{O}-\mathrm{E})^{\wedge} 2 / \mathrm{E}$ \\
\hline LIKES & & & & & \\
Pengalaman & 4 & 4 & 0 & 0 & 0 \\
Lingkungan & 9 & 4 & 5 & 25 & 6 \\
Kerja & 12 & 4 & 8 & 64 & 15 \\
Rekan Kerja & 7 & 4 & 3 & 9 & 2 \\
Pekerjaanya & 7 & 4 & 3 & 9 & 2 \\
Gaji & 2 & 4 & -2 & 4 & 1 \\
Atasan & 3 & 4 & -1 & 1 & 0 \\
Reward & 2 & 4 & -2 & 4 & 1 \\
Tantangan & 1 & 4 & -3 & 9 & 2 \\
Fasilitas & 2 & 4 & -2 & 4 & 1 \\
Kesesuaian & 1 & 4 & -3 & 9 & 2 \\
Pekerjaan & 2 & 4 & -2 & 4 & 1 \\
Sistem Kerja & 52 & 52 & & & 32,77 \\
Others & & & & & \\
Total & & & & & \\
\hline
\end{tabular}


Tabel 2. Tabel Perhitungan Chi-Square (Dislike)

\begin{tabular}{|c|c|c|c|c|c|}
\hline Variabel & Observed & Expected & O-E & $(\mathrm{O}-\mathrm{E})^{\wedge} 2$ & $(\mathrm{O}-\mathrm{E})^{\wedge} 2 / \mathrm{E}$ \\
\hline \multicolumn{6}{|l|}{ DISLIKES } \\
\hline Kerja & 5 & 4 & 1 & 1 & 0 \\
\hline Atasan & 10 & 4 & 6 & 36 & 7 \\
\hline Jam Kerja & 6 & 4 & 2 & 4 & 1 \\
\hline Penjadwal Kerja & 4 & 4 & 0 & 0 & 0 \\
\hline Kerjasama Tim & 6 & 4 & 2 & 4 & 1 \\
\hline Rekan Kerja & 8 & 4 & 4 & 16 & 3 \\
\hline Beban Kerja & 6 & 4 & 2 & 4 & 1 \\
\hline Gaji & 3 & 4 & -1 & 1 & 0 \\
\hline $\begin{array}{l}\text { Fasilitas } \\
\text { Kesesuaian }\end{array}$ & 1 & 4 & -3 & 9 & 3 \\
\hline Pekerjaan & 1 & 4 & -3 & 9 & 3 \\
\hline Sistem Kerja & 1 & 4 & -3 & 9 & 3 \\
\hline Others & 2 & 4 & -2 & 4 & 1 \\
\hline $\begin{array}{l}\text { Total } \\
\text { Improve }\end{array}$ & 53 & 53 & & & 21.490566 \\
\hline Gaji & 3 & 6 & -3 & 9 & 1 \\
\hline Pelatihan & 10 & 6 & 4 & 16 & 3 \\
\hline $\begin{array}{l}\text { Sistem Kerja } \\
\text { Penjadwalan }\end{array}$ & 8 & 6 & 2 & 4 & 1 \\
\hline Kerja & 9 & 6 & 3 & 9 & 2 \\
\hline Fasilitas & 4 & 6 & -2 & 4 & 0 \\
\hline Kerjasama tim & 7 & 6 & 1 & 1 & 0 \\
\hline Beban Kerja & 5 & 6 & -1 & 1 & 0 \\
\hline Lingkungan & 4 & 6 & -2 & 4 & 0 \\
\hline Atasan & 1 & 6 & -5 & 25 & 4 \\
\hline Total & 51 & 51 & & & 12.705882 \\
\hline \multicolumn{6}{|l|}{ Excites } \\
\hline Pengalaman & 2 & 5 & -3 & 9 & 2 \\
\hline Lingkungan & 15 & 5 & 10 & 100 & 18 \\
\hline Gaji & 12 & 5 & 7 & 49 & 8 \\
\hline Rekan Kerja & 9 & 5 & 4 & 16 & 3 \\
\hline Pekerjaanya & 6 & 5 & 1 & 1 & 0 \\
\hline Fasilitas & 1 & 5 & -4 & 16 & 3 \\
\hline Kerjasama tim & 1 & 5 & -4 & 16 & 3 \\
\hline Tantangan & 1 & 5 & -4 & 16 & 3 \\
\hline Jarak & 3 & 5 & -2 & 4 & 1 \\
\hline Others & 3 & 5 & -2 & 4 & 1 \\
\hline Total & 53 & 53 & & & 43.4150943 \\
\hline
\end{tabular}


Kemudian atribut tersebut dijadikan indeks untuk penyebaran kuesioner. Setelah mendapatkan hasil kuesioner maka dilakukan uji validitas dan reabilitas. Pada penelitian ini dilakukan uji validitas untuk 50 kuesioner dan hasil uji didapatkan semua atribut valid dan reliabel. Untuk membuat pemetaan kategori atribut dengan model Kano dengan mengkonversi hasil kuesioner ke dalam A,M,O,R,I,Q (Tabel 3).

Tabel 3. Konversi Kuesioner Kano ke Kategori A,M,O,R,I,Q

\begin{tabular}{cccc}
\hline Pertanyaan & F & D & Hasil \\
\hline 1 & 3 & 5 & M \\
2 & 1 & 5 & O \\
3 & 1 & 4 & A \\
4 & 1 & 5 & O \\
5 & 1 & 3 & A \\
6 & 1 & 3 & A \\
7 & 1 & 3 & A \\
8 & 1 & 4 & A \\
9 & 2 & 4 & I \\
10 & 3 & 5 & M \\
11 & 2 & 3 & I \\
12 & 3 & 4 & I \\
\hline
\end{tabular}

Setelah semua hasil kuesioner di konversi maka di rekapitulasi dan dilakukan tabulasi Kano (Tabel 4).

Tabel 4. Hasil Tabulasi Kategori Kano

\begin{tabular}{cccccccccc}
\hline \multirow{2}{*}{ Atribut } & \multicolumn{4}{c}{ Golongan Kebutuhan } & \multicolumn{3}{c}{ Hasil } & \multirow{2}{*}{$\begin{array}{c}\text { Kategori } \\
\text { Kano }\end{array}$} \\
\cline { 2 - 7 } & $\mathrm{A}$ & $\mathrm{M}$ & $\mathrm{O}$ & $\mathrm{I}$ & $\mathrm{R}$ & $\mathrm{Q}$ & $\mathrm{A}+\mathrm{M}+\mathrm{O}$ & $\mathrm{I}+\mathrm{R}+\mathrm{Q}$ & Kanc \\
\hline 1 & 50 & 31 & 25 & 94 & 0 & 0 & 106 & 94 & $\mathrm{~A}$ \\
2 & 34 & 39 & 48 & 79 & 0 & 0 & 121 & 79 & $\mathrm{O}$ \\
3 & 36 & 37 & 54 & 73 & 0 & 0 & 127 & 73 & $\mathrm{O}$ \\
4 & 35 & 37 & 65 & 63 & 0 & 0 & 137 & 63 & $\mathrm{O}$ \\
5 & 40 & 36 & 49 & 75 & 0 & 0 & 125 & 75 & $\mathrm{O}$ \\
6 & 27 & 37 & 39 & 97 & 0 & 0 & 103 & 97 & $\mathrm{O}$ \\
7 & 35 & 33 & 47 & 85 & 0 & 0 & 115 & 85 & $\mathrm{O}$ \\
8 & 38 & 46 & 39 & 77 & 0 & 0 & 123 & 77 & $\mathrm{M}$ \\
9 & 38 & 43 & 34 & 85 & 0 & 0 & 115 & 85 & $\mathrm{M}$ \\
10 & 23 & 43 & 41 & 93 & 0 & 0 & 107 & 93 & $\mathrm{M}$ \\
11 & 29 & 44 & 46 & 81 & 0 & 0 & 119 & 81 & $\mathrm{O}$ \\
12 & 37 & 28 & 50 & 85 & 0 & 0 & 115 & 85 & $\mathrm{O}$ \\
\hline
\end{tabular}

Setelah didapatkan hasil Tabulasi Kano, selanjutnya dilakukan perhitungan satisfaction dan dyssatisfaction untuk mendapatkan pemetaan katergori atribut. Berikut merupakan rumus yang digunakan dan rekapitulasi perhitungan tersebut. Rekapnya dapat dilihat pada Tabel 5. 


$$
\begin{aligned}
& \text { Satisfaction coefficient }=\frac{A+O}{A+O+M+I} \\
& \text { Dissatisfaction coefficient }=\frac{M+O}{A+O+M+I}
\end{aligned}
$$

Tabel 5. Tabel Perhitungan satisfaction dan dyssatisfaction

\begin{tabular}{ccc}
\hline Atribut & $\begin{array}{c}\text { Satisfaction } \\
\text { Coefficient }\end{array}$ & $\begin{array}{c}\text { Dissatisfaction } \\
\text { Coefficient }\end{array}$ \\
\hline 1 & 0,375 & 0,28 \\
2 & 0,41 & 0,435 \\
3 & 0,45 & 0,455 \\
4 & 0,5 & 0,51 \\
5 & 0,445 & 0,425 \\
6 & 0,33 & 0,38 \\
7 & 0,41 & 0,4 \\
8 & 0,385 & 0,425 \\
9 & 0,36 & 0,385 \\
10 & 0,32 & 0,42 \\
11 & 0,375 & 0,45 \\
12 & 0,435 & 0,39 \\
\hline
\end{tabular}

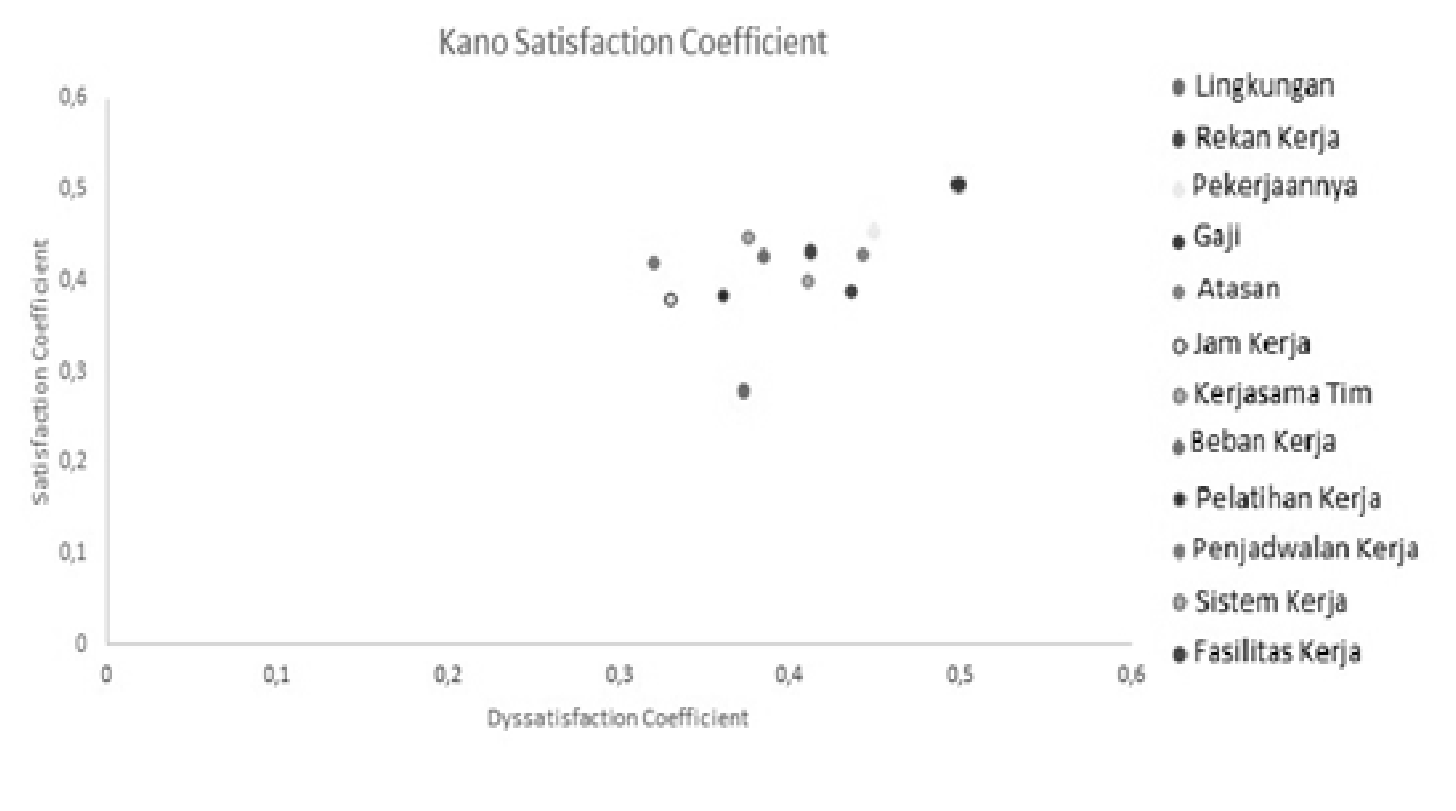

Gambar 2. Diagram Pemetaan Kepuasan Model Kano

Setelah mendapatkan diagram pemetaan kepuasan model Kano (Gambar 2) maka dilakukan perhitungan untuk mendapatkan pemetaan dengan menggunakan metode IGA. Untuk melakukan pemetaan metode ini dibutuhkan nilai eksplisit (EI) dan Implisit (II). Nilai eksplisit 
didapatkan dari satisfaction coefficient sedangkan nilai II didapatkan dari nilai pearson correlation pada tabel correlation total pada uji validitas tingkat kepentingan (Tabel 6).

Tabel 6. Tabel Nilai Eksplisit dan Implisit Pemetaan Kategori Kano

\begin{tabular}{clcc}
\hline No. & \multicolumn{1}{c}{ Atribut } & Eksplisit & Implisit \\
\hline 1 & Lingkungan Kerja & 0,562 & 0,375 \\
2 & Rekan Kerja & 0,582 & 0,41 \\
3 & Pekerjaannya & 0,282 & 0,45 \\
4 & Gaji & 0,456 & 0,5 \\
5 & Sikap Atasan & 0,508 & 0,445 \\
6 & Jam Kerja & 0,377 & 0,33 \\
7 & Kerjasama Tim & 0,506 & 0,41 \\
8 & Beban Kerja & 0,351 & 0,385 \\
9 & Pelatihan Kerja & 0,527 & 0,36 \\
10 & Penjadwalan Kerja & 0,47 & 0,32 \\
11 & Sistem Kerja & 0,463 & 0,375 \\
12 & Fasilitas Kerja & 0,543 & 0,435 \\
& Rata-rata & 0,469 & 0,4 \\
\hline
\end{tabular}

\section{Importance Grid Analysis}

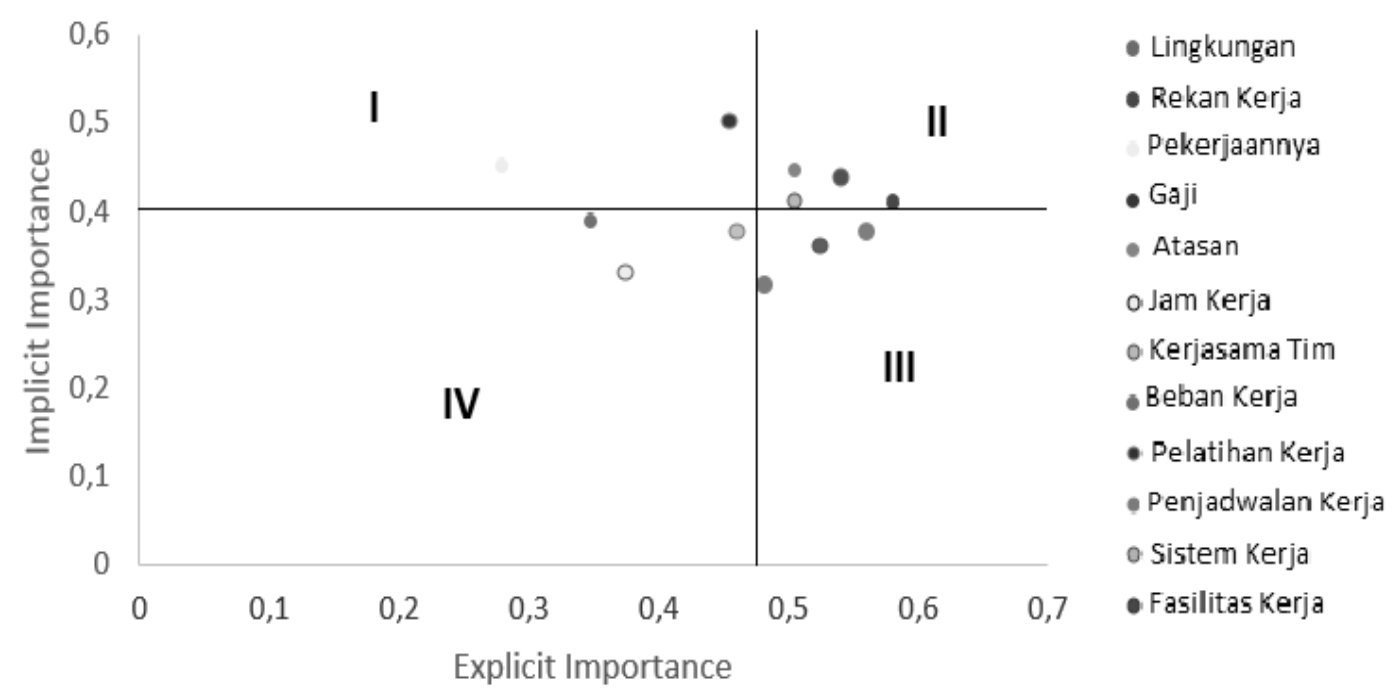

Gambar 3. Diagram IGA

Setelah mendapatkan pemetaan kategori atribut Kano, dengan menggunakan metode IGA maka tiap atribut dianalisis untuk mengetahui atribut mana yang harus diprioritaskan oleh perusahaan untuk memenuhi kepuasan para karyawan yang bekerja kurang dari 1 tahun. Tabel rekapitulasi hasil integrasi Kano-IGA dapat dilihat pada Tabel 7. 
Tabel 7. Rekapitulasi Hasil Integrasi Kano-IGA

\begin{tabular}{|c|c|c|c|}
\hline Atribut & Kano & IGA & Keterangan \\
\hline $\begin{array}{l}\text { Lingkungan } \\
\text { Kerja }\end{array}$ & A & III & $\begin{array}{l}\text { Atribut ini berada pada kuadran III maka pemenuhan kebutuhan ini } \\
\text { harus dipenuhi setelah atribut pada kuadran II dan I terpenuhi. } \\
\text { atribut ini masuk dalam kuadran yang memiliki tingkat kepentingan }\end{array}$ \\
\hline Rekan Kerja & $\mathrm{O}$ & II & $\begin{array}{l}\text { dan kepuasan sangat tinggi. Jika suatu perusahaan tidak memenuhi } \\
\text { atribut ini maka para karyawan sudah pasti merasa tidak puas. }\end{array}$ \\
\hline $\begin{array}{l}\text { Pekerjaan } \\
\text { itu sendiri }\end{array}$ & $\mathrm{O}$ & I & $\begin{array}{l}\text { Karyawan menganggap atribut ini tidak terlalu penting tetapi jika } \\
\text { kebutuhan tidak terpenuhi maka mereka akan sangat tidak puas }\end{array}$ \\
\hline Gaji & $\mathrm{O}$ & I & $\begin{array}{l}\text { Sama halnya dengan atribut pekerjaannya, atribut ini juga tidak } \\
\text { terlalu penting karena mereka menganggap sudah selayaknya } \\
\text { perusahaan memberikan gaji. Tetapi jika atribut gaji ini tidak } \\
\text { terpenuhi maka para karyawan akan berpengaruh terhadap kepuasan } \\
\text { kerja karyawan. jika dibandingkan atribut pekerjaan, atribut gaji ini } \\
\text { harus lebih didahulukan pemenuhannya. }\end{array}$ \\
\hline Atasan & $\mathrm{O}$ & II & $\begin{array}{l}\text { Sama seperti atribut rekan kerja, atribut ini juga sangat } \\
\text { terhadap kepuasan karyawan. Jika atribut ini tidak se } \\
\text { keinginan mereka maka para karyawan sudah pasti tidak }\end{array}$ \\
\hline Jam Kerja & $\mathrm{O}$ & IV & $\begin{array}{l}\text { Atribut ini merupakan atribut terakhir yang harus dipenuhi oleh } \\
\text { perusahaan dari pada ke sebelas atribut lainnya karena masuk pada } \\
\text { kuadran IV dan memiliki nilai paling kecil dibanding atribut yang } \\
\text { berada pada kuadran tersebut. }\end{array}$ \\
\hline $\begin{array}{l}\text { Kerjasama } \\
\text { Tim }\end{array}$ & $\mathrm{O}$ & II & $\begin{array}{l}\text { Kerjasama tim merupakan atribut yang pemenuhannya harus } \\
\text { dipenuhi terlebih dahuku dibandingkan atribut pada kuadran I yaitu } \\
\text { gaji dan pekerjaanya sehingga para karyawan merasa puas dalam } \\
\text { bekerja. }\end{array}$ \\
\hline Beban Kerja & M & IV & $\begin{array}{l}\text { tribut ini prioritas pemenuhannya tidak terlalu tinggi dibandingkan } \\
-3 \text { kuadran lainnya. }\end{array}$ \\
\hline $\begin{array}{l}\text { Pelatihan } \\
\text { Kerja }\end{array}$ & M & III & $\begin{array}{l}\text { Sama seperti atribut lingkungan kerja, atribut ini juga harus dipenuhi } \\
\text { setelah perusahaan memenuhi kebutuhan atribut pada kuadran II dan } \\
\text { I }\end{array}$ \\
\hline $\begin{array}{l}\text { Penjadwalan } \\
\text { Kerja }\end{array}$ & M & III & $\begin{array}{l}\text { Atribut ini dipenuhi ketika atribut padakuadran II dan I terpenuhi } \\
\text { karena atribut ini masuk pada kuadran III yang berarti tidak lebih } \\
\text { penting dari kuadran I dan II tetapi memiliki tingkat kepuasan yang } \\
\text { tinggi }\end{array}$ \\
\hline $\begin{array}{l}\text { Sistem } \\
\text { Kerja }\end{array}$ & $\mathrm{O}$ & IV & $\begin{array}{l}\text { Sama seperti atribut beban kerja, atribut ini juga pemenuhan } \\
\text { kebutuhannya dilakukan setelah atribut yang berada pada kuadran I, } \\
\text { II, dan III sudah terpenuhi. }\end{array}$ \\
\hline $\begin{array}{l}\text { Fasilitas } \\
\text { Kerja }\end{array}$ & $\mathrm{O}$ & II & $\begin{array}{l}\text { Selain rekan kerja, atasan, dan kerjasama tim, atribut ini juga masuk } \\
\text { dalam kategori yang harus diprioritaskan oleh suatu perusahaan agar } \\
\text { para karyawan merasa puas. }\end{array}$ \\
\hline
\end{tabular}

\section{KESIMPULAN DAN SARAN}

Berdasarkan pengolahan data dan analisa, maka penulis dapat menarik beberapa buah kesimpulan yaitu :

1. Untuk mendapatkan faktor-faktor atau atribut kepuasan karyawan digunakan diagram afinitas yang mengelompokkan kesamaan arti pada hasil kuesioner pendahuluan. Kemudian setelah dirangkum dengan perhitungan Chi-Square terhadap masing-masing pertanyaan menyangkut kesukaan, ketidaksukaan, hal yang dapat ditingkatkan oleh perusahaan, dan hal yang membuat karyawan kembali bekerja setiap harinya, peneliti mendapatkan 12 faktor atau atribut kepuasan kerja karyawan yang bekerja pada perusahaan jasa kurang dari 1 tahun yaitu: lingkungan kerja, rekan kerja, pekerjaannya, gaji, atasan, jam kerja, kerjasama tim, beban kerja, pelatihan kerja, sistem kerja, dan fasilitas. 
2. Pada penelitian ini didapatkan 3 kelompok kategori pada model Kano. Kategori tersebut yaitu attractive, one-dimensional, dan must-be. Untuk kelompok kategori atribut model kano must-be terdapat 3 atribut yang harus terpenuhi yaitu beban kerja, pelatihan kerja, dan penjadwalan kerja. Jika kategori ini tidak terpenuhi maka karyawan tidak akan puas. Kategori ini sudah seharusnya dimiliki oleh setiap perusahaan jasa. Yang kedua yaitu kelompok kategori one-dimensional. Pada kelompok kategori ini terdapat 8 atribut kepuasan karyawan yaitu rekan kerja, pekerjaannya, gaji, atasan, jam kerja, kerjasama tim, sistem kerja, dan fasilitas kerja. Pada kelompok kategori ini kepuasan karyawan tergantung pada seberapa besar atribut tersebut terpenuhi oleh perusahaan. Semakin tinggi atribut tersebut terpenuhi maka akan semakin tinggi kepuasan kerja karyawan. Dan yang ketiga yaitu attractive. Pada kelompok kategori ini hanya ada 1 atribut yaitu lingkungan kerja. Pada kelompok ini jika atribut tersebut terpenuhi, karyawan akan merasa puas tetapi jika tidak terpenuhi karyawan tidak merasa kecewa.

3. Pemetaan atribut dengan menggunakan metode IGA menghasilkan atribut-atribut yang harus diprioritaskan dan memiliki dampak yang kuat pada kepuasan kerja karyawan. Atribut yang memiliki prioritas tinggi dan harus terpenuhi yaitu berada pada kuadran II. Atribut yang berada pada kuadran ini adalah rekan kerja, fasilitas kerja, atasan, dan kerjasama tim. Sedangkan prioritas kedua atau prioritas umum yang harus terpenuhi ada pada kuadran 1 yaitu gaji dan pekerjaannya. Sedangkan atribut dengan prioritas ketiga adalah atribut yang jika terpenuhi atau tidak, pengaruhnya kecil terhadap kepuasan karyawan ada pada kuadran III yaitu lingkungan kerja, pelatihan kerja, dan penjadwalan kerja. Sedangkan pada kuadran IV yang memiliki prioritas dan dampak kepuasan yang sangat kecil yaitu sistem kerja, jam kerja dan beban kerja.

Adapun saran-saran yang diberikan kepada perusahaan, antara lain:

1. Perusahaan dapat mengevaluasi faktor kepuasan yang belum terpenuhi dalam perusahaannya agar karyawan yang bekerja kurang dari 1 tahun atau karyawan yang belum tetap agar merasakan kepuasan dalam bekerja, hal tersebut akan membuat karyawan menyenangi pekerjaannya dan dengan sendirinya mereka akan bersikap loyal terhadap perusahaan di mana mereka bekerja.

2. Perusahaan dapat mengevaluasi dengan kuesioner atau wawancara langsung dengan para karyawan agar dapat mengetahui atribut atau faktor-faktor apa saja yang membuat para karyawan yang bekerja kurang dari 1 tahun merasakan kepuasan kerja.

3. Perusahaan sebaiknya memberi prioritas terhadap faktor-faktor yang membuat karyawan merasakan kepuasan kerja.

\section{DAFTAR PUSTAKA}

[1] Byars, L.L., and Rue, L.W., 2005, Human Resources Management, McGraw-Hill, New York.

[2] Fan, L., Sukwadi, R., and Moon, J.Y., 2015, Creating an innovative marketing strategy based on Kano-Blue Ocean Approach, The Journal of the Korea Contents Association, 15(12), 534-540.

[3] Hasibuan, M., 2007, Manajemen Sumber Daya Manusia, Bumi Aksara, Jakarta.

[4] Kano, N., Seraku, N., Takahashi, F., and Tsuji, S., 1984, Attractive quality and must-be quality. Hinshitu, 14(2),147-156.

[5] Kinicki, A., and Kreitner, R., 2005, Organizational Behavior: Key concepts skills and best Practice, McGraw-Hill, New York.

[6] Mikulić J, and Prebežac, D., 2011, Rethinking the importance grid as a research tool for quality managers. Total Quality Management \& Business Excellence, 22, 993-1006.

[7] Nelson, D.L., and Quick, J.C., 2006, Organizatonal Behavior Foundations Realities and Challenges, Thompson South Western, USA.

[8] Noe, R.A., et al., 2006, Human Resources Management, McGraw-Hill, New York. 
[9] Robbins, S.P., \& Judge, T.A., 2017, Organizational Behavior, $1^{\text {5th }}$ ed., Prentice Hall, New York.

[10] Sukwadi, R., and Agustin, D., 2016, Analisis kualitas layanan restoran dengan menggunakan model Kano-PRCA dan AIM, Spektrum Industri, 14(1), 89-98.

[11] Sukwadi, R., Inderawati, M.M.W., and Lie, V., 2015, Pengembangan strategi perbaikan kualitas layanan Taman Hiburan Dunia Fantasi Ancol, Journal of Industrial Engineering \& Management Systems, 8(1), 55-69.

[12] Sukwadi, R. \& Meliana, M., 2014, Faktor-faktor yang mempengaruhi kinerja dan turn over intention karyawan usaha kecil menengah, Jurnal Rekayasa Sistem Industri, 3(1), 1-9.

[13] Sukwadi, R., \& Yang, C.C., 2014, Determining service improvement priority in a zoological park. Journal of Industrial Engineering and Management, 7(1), 1-20.

[14] Witell, L., and Lofgren, M., 2007, Classification of quality attributes, Journal of Managing Service Quality, 17(1), 54-73. 